\title{
JUS JAMBU BIJI MERAH DAN KONSTIPASI PADA IBU HAMIL TRIMESTER III
}

\author{
I'in Ningtias, Suprapti, Ardi Panggayuh \\ Poltekkes Kemenkes Malang, Jalan Besar Ijen 77C Malang \\ Email: suprapti@poltekkes-malang.ac.id
}

\section{Red Guava Juice Againts Constipation in Third Trimester Pregnant Women}

\begin{abstract}
To reduce the occurrence of constipation, pregnant women can reproduce high-fiber foods. WHO recommends fiber intake of 25-30 g / day. Guava fiber content on a per $100 \mathrm{~g}$ as much 5,4g. The purpose of this study was to analyze the effect of red guava juice against constipation in third trimester pregnant women in health centers Ciptomulyo. Population 73 respondents, the sampling using purposive sampling technique, the total sample of 26 pregnant woman who have received treatment. The results of the study with a computerized calculation with a value of $\alpha=0.05$ is obtained Sig . ( 2 - tailed) $=0,036$ so $\rho$ value $0,036<\alpha=0.05$, it can be concluded Ho rejected, which means there is the influence of red guava juice with constipation in third trimester pregnant women.
\end{abstract}

Keywords: constipation, guava juice

\begin{abstract}
Abstrak: WHO menganjurkan asupan serat 25-30 g/hr. Serat bisa diperoleh dari buah-buahan, salah satunya buah yang tinggi serat yaitu jambu biji merah, kandungan serat pada jambu biji per $100 \mathrm{~g}$ sebanyak 5,4g. Tujuan dari penelitian ini adalah untuk menganalisa pengaruh jus jambu biji merah terhadap konstipasi pada ibu hamil trimester III di Puskesmas Ciptomulyo. Populasi sebanyak 73 responden, sampling menggunakan tehnik purposive sampling, jumlah sampel 26 ibu hamil yang mengalami konstipas. Dianalisa menggunakan Spearmann Rank Test. Hasil penelitian dengan perhitungan komputerisasi dengan nilai $\alpha=0,05$ didapatkan hasil Sig. (2-tailed) $=0,036$ sehingga $\rho$ value $0,036<\alpha=0,05$, maka dapat disimpulkan $H_{0}$ ditolak yang artinya ada pengaruh jus jambu biji merah dengan konstipasi pada ibu hamil trimester III.
\end{abstract}

Kata Kunci: jus jambu biji merah, konstipasi

\section{PENDAHULUAN}

Kehamilan merupakan saat yang ditunggu oleh sebagian besar wanita. Kehamilan dibagi dalam 3 triwulan yaitu triwulan pertama dimulai dari konsepsi sampai 3 bulan, triwulan kedua dari bulan keempat sampai 6 bulan, triwulan ketiga dari bulan ketujuh sampai 9 bulan (Prawirohardjo, 2010). Pada masa ini terjadi perubahan fisiologis mulai dari perubahan metabolik, kardiovaskular, hematologi, sistem respirasi, sistem renal, sistem gastrointestinal, sistem saraf pusat dan perifer, sistem muskuloskeletal, sirkulasi uteroplasental dan perubahan hormonal (Prawirohardjo, 2010). Dari perubahan tersebut bisa menimbulkan rasa ketidaknyamanan pada ibu hamil.

Banyak ibu hamil yang mengalami ketidaknyamanan disetiap masa kehamilan yang berbeda, salah satunya adalah konstipasi. Konstipasi ini sering muncul pada trimester 3 . Konstipasi adalah gejala defikasi yang tidak memuaskan yang ditandai dengan buang air besar kurang dari 3 kali dalam 1 minggu atau kesulitan dalam evakuasi feses akibat feses yang keras (Konsensus PGI, 2006), hal ini karena frekuensi pergerakan usus berkurang, yang akhirnya memperpanjang masa transit tinja. Semakin lama tinja tertahan didalam usus maka konsentrasinya akan mengeras, dan akhirnya membatu sehingga susah dikeluarkan (Arisman, 2010). Dalam buku Gizi untuk Kebidanan, permasalahan konstipasi pada ibu hamil ini dikarenakan peningkatan hormon progesteron yang membuat pergerakan otot pada usus besar melambat (Proverawati, 2009), gejalanya antara lain kembung, rasa tidak nyaman pada perut, selain itu komplikasi pada 
konstipasi kronik antara lain prolaps rekti, perdarahan hemoroid, fisura ani, impaksi feses yang dapat menyebabkan obstruksi kolon yang dapat menimbulkan perdarahan, juga bisa terjadi infeksi saluran kemih berulang karena kompresi ureter akibat skibala (Konsensus PGI, 2006), maka ibu hamil perlu waspada bila mengalami konstipasi pada kehamilan.

Prevalensi wanita hamil yang mengalami konstipasi sebanyak $24 \%$ pada trimester pertama, trimester kedua sebanyak $26 \%$ dan trimester ketiga sebanyak 26\% (Bradley, 2007), dan diperkirakan 11-38 \% wanita hamil mengalami konstipasi (Trottier, 2012). Konstipasi merupakan etiologi haemoroid yang paling sering. Kejadian hemoroid pada wanita hamil diestimasi $25-35 \%$ dan $85 \%$ pada trimester ketiga (Staroselsky, 2008). Hemoroid meningkat pada 1/3 wanita selama masa kehamilan (Malangoni Ma, 2003). Data pada bulan september 2015 di Puskesmas Ciptomulyo pada saat pemeriksaan ANC didapatkan 18 ibu hamil trimester 3 dengan keluhan konstipasi.

Konstipasi yang terjadi pada ibu hamil trimester III menyebabkan kolon sigmoid penuh oleh skibala yang keras. Penumpukan skibala yang keras tersebut dapat menghambat penurunan kepala. Selain itu, feses yang keras akan sulit dikeluarkan saat proses buang air besar. Hal ini berdampak pada saluran cerna bagian bawah yaitu rektum dan anus yang mengalami pelebaran pembuluh darah yang sering disebut hemoroid atau wasir. Kondisi hemoroid tersebut menjadi lebih parah setelah proses persalinan.

Untuk mengurangi terjadinya konstipasi selama kehamilan, ibu hamil dapat memperbanyak minum cairan agar proses mencerna di usus menjadi lebih baik. Selain itu ibu dapat memperbanyak makanan yang berserat tinggi (Proverawati, 2009). Diet berserat tinggi mempertahankan kelembaban tinja dengan cara menarik air secara osmotis ke dalam tinja dan dengan merangsang peristaltik kolon melalui peregangan (Corwin, 2000). Dalam ilmu gizi, serat berasal dari sayuran dan buah disebut dengan serat kasar (crude fiber). WHO menganjurkan asupan serat 25-30 g/hr (Almatsier, 2010). Seperti yang dimuat dalam Riskesdas 2013 tentang perilaku pola konsumsi buah dan sayur, penduduk Indonesia memiliki kecenderungan kurang mengkonsumsi buah dan sayur khususnya wilayah Jawa Timur memiliki 90\% kecenderungan proporsi penduduk $\geq 10$ tahun kurang mengkonsumsi buah dan sayur. Salah satu buah-buahan yang tinggi serat yaitu jambu biji merah, kandungan serat pada jambu biji per 100g sebanyak 5,4g (Putra, 2013) dan 1 buah jambu biji besar mengandung 22,5g serat (Almatsier, 2010). Saat ini jambu biji merah marak beredar di pasaran, karena manfaatnya yang banyak dan harganya yang terjangkau dan apabila dijadikan jus akan menarik perhatian dengan warna merah pada jambu biji itu sendiri.

Tujuan penelitian ini adalah untuk menganalisa pengaruh jus jambu biji merah terhadap konstipasi pada ibu hamil trimester III di Puskesmas Ciptomulyo

\section{METODE PENELITIAN}

Penelitian ini menggunakan desain penelitian Pre-eksperimental dengan rancangan One Group Pretest Postest.

Populasi dalam penelitian ini adalah seluruh ibu hamil trimester III di wilayah Puskesmas Ciptomulyo pada bulan Mei-Juni sebanyak 78 responden. Sampel dalam penelitian ini ibu hamil trimester III. Kriteria sampel sebagai berikut 1) Usia kehamilan 25-37 minggu yang mengalami konstipasi, 2) Ibu hamil trimester III usia kehamilan 25-37 minggu yang mengalami konstipasi, 3) Ibu hamil resiko rendah berdasarkan Kartu Skor Pudji Rochyati, 4) Ibu hamil yang tinggal di wilayah Ciptomulyo, Gadang dan Kebonsari. Teknik sampling yang digunakan adalah purposive sampling.

Tempat penelitian adalah Puskesmas 
Ciptomulyo pada bulan Mei sampai Agustus 2016.

Variabel penelitian menggunakan dua variabel, yaitu Dependent Variabel: Jus Jambu Biji Merah, Independent Variabel: Konstipasi.

Jus jambu biji merah dibuat dari 400 gr jambu biji merah ditambah $100 \mathrm{ml}$ air es dan 1 sdm gula putih yang dihaluskan menggunakan mesin penghalus (blender). Diberikan maksimal selama 6 hari.

Setelah ibu hamil setuju menjadi responden, peneliti memberikan informed consent. Mengidentifikasi konstipasi responden menggunakan checklist. Responden yang mengalami konstipasi diberikan jus jambu yang diminum pada saat perut kosong yaitu 1 jam sebelum makan siang. Jus jambu dibuat oleh peneliti, yang membutuhkan waktu sekitar 3 menit untuk 1 takaran jus jambu, kemudian jus jambu dihantarkan kepada responden dengan menggunakan tempat khusus yang berisi es untuk mempertahankan kesegaran jus jambu. Peneliti bekerjasama dengan rekan sejawat untuk proses pengiriman kepada responden. Pukul 10.45 jus jambu siap diantarkan kepada responden, jarak rumah responden dan peneliti maksimal membutuhkan waktu 15 menit. Setelah sampai kepada responden, peneliti yang dibantu rekan sejawat menunggu sampai jus jambu selesai diminum saat itu juga oleh ibu hamil. Setiap hari peneliti melakukan evaluasi keberhasilan jus jambu terhadap konstipasi pada ibu hamil dengan menanyakan langsung waktu pemberian jus hari berikutnya. Pemberian jus jambu dihentikan jika responden sudah tidak mengalami konstipasi, dan responden dikeluarkan dari kriteria jika masih mengalami konstipasi sampai 6 hari pemberian jus jambu. Peneliti mencatat hasil dalam lembar checklist.

Pengujian hipotesis untuk mengetahui adanya pengaruh yang signifikan pada penelitian jus jambu biji merah terhadap konstipasi dilakukan dengan Uji Spearman Rank.
Kriteria penelitian jika $\mathrm{r}$ hitung lebih besar dari $\mathrm{r}$ tabel, maka Ho ditolak, dan $\mathrm{H}_{1}$ diterima dengan $\alpha=0,05$ artinya ada pengaruh jus jambu biji merah terhadap konstipasi ibu hamil, sebaliknya, jika $r$ hitung lebih kecil dari $r$ tabel maka Ho diterima, dan $\mathrm{H}_{1}$ ditolak dengan $\alpha=0,05$ artinya tidak ada pengaruh jus jambu biji merah terhadap konstipasi ibu hamil.

\section{HASIL PENELITIAN}

Karakteristik responden berdasarkan usia diketahui bahwa sebagian besar responden memiliki usia 20-35 tahun 80,8\% dan 19,2\% memiliki usia $>35$ tahun.

Karakteristik berdasarkan usia kehamilan responden, dapat diketahui sebanyak $66 \%$ mempunyai usia kehamilan 22-28 minggu, 17\% usia kehamilan 29-32 minggu, dan 17\% dengan usia kehamilan 33-37 minggu.

Diketahui bahwa gravida responden $25 \%$ primigravida dan $75 \%$ multigravida.

Pengaruh jus jambu biji merah terhadap konstipasi wanita hamil trimester ketiga ditunjukkan pada Gambar 1, dimana sebelum pemberian jus jambu, sebanyak 19 responden (73\%) mengalami sedikit konstipasi, sedangkan pada responden yang sudah diberi jus jambu sebanyak 19 responden (73\%) tidak mengalami konstipasi atau dalam kategori normal.

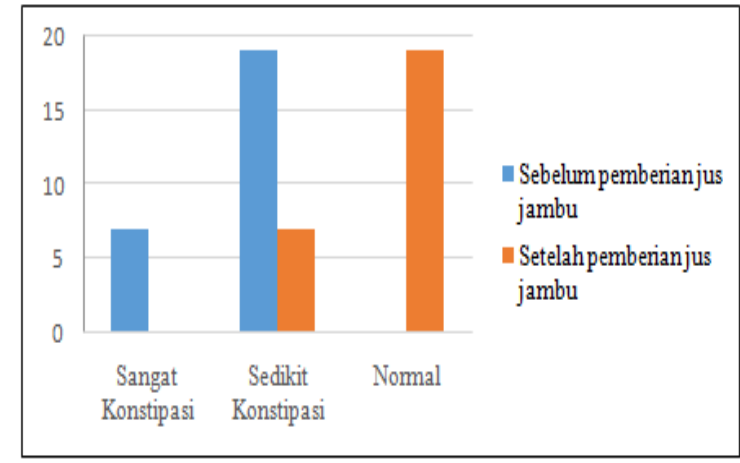

Gambar 1. Pengaruh Jambu Biji Merah terhadap Konstipasi 
Pengujian hipotesis penelitian dengan menggunakan uji statistik korelasi Spearman Rank dengan nilai $\alpha=0,05$ didapatkan hasil Sig. (2-tailed) $=0,036$ sehingga $\rho$ value $=0,036$ $<\alpha=0,05$ maka dapat disimpulkan $\mathrm{H}_{0}$ ditolak yang artinya ada pengaruh jus jambu biji merah dengan konstipasi pada ibu hamil trimester III.

\section{PEMBAHASAN}

Selama proses kehamilan terjadi berbagai perubahan metabolisme dalam tubuh, salah satunya perubahan sistem gastrointestinal berupa konstipasi. Pengeluaran feses secara normal, terjadi sekali atau dua kali setiap 24 jam (Akmal, 2010). Kotoran yang keras dan sulit dikeluarkan merupakan efek samping yang tidak nyaman dari kehamilan yang disebut dengan konstipasi. Konstipasi terjadi karena hormon progesteron memperlambat transit makanan melalui saluran pencenaan dan rahim yang membesar menekan poros usus (rektum). Selain itu, rahim yang semakin membesar akan menekan rectum dan usus bagian bawah, sehingga terjadi sembelit atau konstipasi. Sembelit semakin berat karena gerakan otot didalam usus diperlambat oleh tingginya kadar progesterone sehingga perjalanan makanan sampai ke dubur memerlukan waktu yang lebih panjang dan hal tersebut menjadi salah satu penyebab konstipasi. Konstipasi awalnya terjadi karena adanya tekanan pembuluh darah dibagian bawah tubuh akibat membesarnya rahim seiring dengan bertambahnya usia kehamilan. Konstipasi memiliki berbagai gejala seperti susah buang air besar, kembung, atau bentuk kotoran keras dan kecil kecil.

Sejumlah faktor yang mempengaruhi konstipasi selama kehamilan antara lain kekurangan serat merupakan salah satu hal penyebab konstipasi (Proverawati, 2010). Konsumsi serat pangan yang cukup, akan memberibentuk, meningkatkan air dalam feses menghasilkan feses yang lembut dan tidak keras sehingga hanya dengan kontraksi otot yang rendah feses dapat dikeluarkan dengan lancar.

Konstipasi dapat diatasi dengan diet tinggi serat. Diet tinggi serat adalah modifikasi dari susunan makanan biasa dengan menambah bahan pangan yang banyak mengandung serat pangan. Serat pangan paling tinggi salah satunya didapatkan pada buah jambu biji merah. Dalam satu buah jambu terkandung 5,4gram/100gram. Serat pada buah jambu dapat meningkatkan kadar air dalam feses sehingga feses akan menjadi lunak. Hal ini yang dimanfaatkan oleh peneliti untuk mengurangi kejadian konstipasi pada ibu hamil.

Dalam penelitian ini sebagian besar responden mengalami perubahan konsistensi feses setelah diberikan jus jambu biji merah. Dari sebagian responden dengan jenis konsistensi feses sangat konstipasi menjadi sedikit konstipasi dan sebagian besar jenis konsistensi feses normal. Begitu pula dari sebagian besar responden dengan jenis konsistensi feses sedikit konstipasi menjadi sebagian besar jenis konsistensi feses normal, sehingga konstipasi yang dialami berkurang. Hal ini berhubungan dengan konsumsi serat pangan yang cukup, akan memberi bentuk dan meningkatkan air dalam feses meghasilkan feces yang lembut dan tidak keras sehingga hanya dengan kontraksi otot yang rendah feses dapat dikeluarkan dengan lancar. Seperti anjuran WHO tentang kadar serat tinggi yaitu sejumlah 25-30 gr per harinya. Namun, konstipasi pada ibu hamil tidak dapat dihilangkan seluruhnya, karena kostipasi tersebut dapat disebabkan oleh berbagai faktor.

Faktor-faktor penyebab konstipasi pada ibu hamil tidak hanya berdasarkan konsumsi serat saja, namun ada berbagai macam faktor seperti:pembesaran rahim yang menekan kolon, perubahan hormonal, asupan cairan yang tidak adekuat, diet serat tidak cukup, suplementasi zat besi, jarang berolahraga, dan kebiasaan defekasi yang buruk (Proverawati 2010).

Pemberian jus jambu memiliki pengaruh yang 
cukup signifikan untuk mengurangi konstipasi pada ibu hamil, untuk itu ibu hamil yang mengalami konstipasi dapat diberikan terapi untuk mengkonsumsi jus jambu satu kali per hari. Di dalam jus jambu mengandung banyak serat, vitamin-vitamin, mineral dan elektrolit yang dapat meningkatkan kadar air dalam feses sehingga menghasilkan feses yang lembut dan menurunkan kontraksi otot.

\section{PENUTUP}

Ibu hamil trimester III yang menjadi responden dalam penelitian ini sebelum diberikan jus jambu biji merah sebagian besar jenis konsistensi feses sedikit konstipasi sebanyak 73\% (19 responden). Sebagian besar responden sesudah diberikan jus jambu biji merah mengalami perubahan jenis konsistensi feses menjadi normal yaitu sebanyak $73 \%$. Sehingga dapat disimpulkan pemberian jus jambu memiliki pengaruh yang cukup signifikan untuk mengurangi konstipasi pada ibu hamil.

Penelitian ini diharapkan menjadi dasar adanya kebijakan tentang konseling yang lebih mendalam terhadap keluhan ibu hamil tentang konstipasi yang selama ini belum pernah terkaji, karena sebagai tempat pelayan kesehatan hendaknya memahami keseluruhan terhadap keluhan-keluhan pasien agar penanganan yang dilakukan bisa lebih maksimal.

\section{DAFTAR PUSTAKA}

Almatsier, S. (2004). Penuntun Diet. Jakarta: PT. Gramedia Pustaka Utama.

Arisman. (2004). Gizi dalam Daur Kehidupan. Jakarta: EGC.

Bradley. (2007). Constipation in pregnancy. Jakarta : EGC.

Brunner \& Suddarth. (2002). Keperawatan Medikal Bedah. Jakarta: EGC.

Carpenito. (2006). Buku Saku Diagnosa Keperawatan. Jakarta : EGC.

Corwin, E. (2000). Buku Saku Patofisiologi. Jakarta: EGC.

Malangoni. (2003). Gastrointestinal Surgery And Pregnancy. North Am: Gastro Clin.

Trottier. (2012). Treating Constipation During Pregnancy. Canadian : Familly Physician Vol 58 